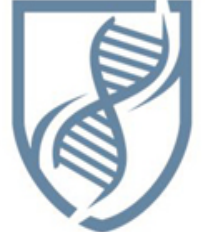

Journal of Bioscience and Applied Research

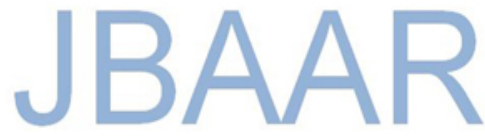

WWW.JBAAR.ORG

\title{
Toxic effects of some pesticides on the enzymatic activities and spermatogenesis of the land snail Monacha cantiana
}

\author{
Sharaf, H.M. , Abd El-Atti M.S. and Salama, M.A. \\ Zoology Department, Faculty of Science, Zagazig University, Egypt. \\ *Corresponding author e.mail: Sharaf_hesham@yahoo.com.
}

\begin{abstract}
Laboratory studies have been carried out on the toxic effects of three different pesticides namely, Diazinon, Lambdacyhalothrin and Methomyl as poisonous baits against the land snail, Monacha cantiana. The activities of five vital tissue enzymes, as Catalase (CAT), Malondialdehyde (MDA), Aspartate transaminase (AST). Alanine transaminase(ALT) and Alkaline phosphatase (ALP) were examined after exposure of these snails to $\mathrm{LC}_{50}(5 \mathrm{ppm})$ of the tested pesticides for 96hr. Results showed clearly that all sublethal concentrations of tested pesticides lead to a significant increase in the activities of the enzymatic levels within tissues of treated snails. On the other hand, $\mathrm{LC}_{25}$ (2.5 ppm) of Diazinon was found to produce severe histopathological alterations in the hermaphrodite gland of M. cantiana, including, deterioration in germinal epithelium of the acini spermatocytes as well as reduction in numbers of sperms which are inhibited to develop to the late stages of maturity.
\end{abstract}

Key words. Enzymes, Monacha cantiana, Pesticides, Spermatogenesis.

\section{Introduction}

In Egypt, the land snail, Monacha cantiana became one of the most important agricultural pests causing substantial damages to different crops in the Egyptian Nile Delta, Mediterranean coast and new reclaimed lands Genena (2003). The importance of terrestrial gastropods as crop pests has greatly increased, and in the process demands for effective control has outstripped the development of chemical control measures Ebenso et al.,(2005). Control of snails on different crops was heavily dependent on the use of pesticides that limit the effect of these pests below damaging level. The synthetic pesticides are the most effective measures available at present for controlling terrestrial gastropods Zedan et al., (2006). However, some of these pesticides were environmentally very stable, which meant that the risk of accumulation was very high, and as a result, permission to use them as pesticides has been restricted Ohayo et al.,(1997). Thus, we are in need for new and safe pesticides with different mode of actions.

Diazinon is a nonsystemic organophosphate insecticide formerly used to control insects and agricultural pests (Sharom et al., 1980) and Geller et al., 2003). Diazinon was highly toxic to snakehead fish Chianna striata, with a 96h LC50 of $0.79 \mathrm{mg} / \mathrm{L}$ and caused long-term $\mathrm{AChE}$ inhibition (Alahyary et al., 2008). Residues of Diazinon and Profenofos pesticides affected antioxidant enzymes and caused a reduction in survival rate in treated Biomophalaria alexandrina snails (Bakry et al., 2013). Pyrethroids , including Lambdacyhalothrin, disrupted functions of the nervous system of insects and caused paralysis or death. It is highly toxic to many fish and aquatic invertebrates (Vijverberg and van den Bercken 
1982). Carbamate pesticides were known to act as nerve toxins by inhibition of cholinesterase (Wilkinson, ,1976) and Young, and Wilkins 1989). Methomyl is a carbamate insecticide and is highly toxic to humans (Imevbore and Ajayi ,1993). Methomyl is used as an ovicide against cotton bollworms and budworms (Howard ,1991). The enzymes selected in this study1 to evaluate the toxic effects of the tested pesticides were (CAT), (MDA), (AST), (ALT) and (ALP). Catalase is a common enzyme found in nearly all living organisms exposed to oxygen and protects the cell from oxidative damage (Góth and Bigler ,2001). Malondialdehyde (MDA) is a marker for oxidative stress. Malondialdehyde results from lipid peroxidation of polyunsaturated fatty acids and the degree of lipid peroxidation can be estimated by the amount of malondialdehyde in tissues (Davey et al., 2005) and Felix Wróblewski et al., 1956). Aspartate transaminase (AST) is widely distributed in animal and commonly measured clinically as biomarkers for liver health (Ghouri et al., 2010). Alkaline phosphatase (ALP) is a hydrolase enzyme responsible for removing phosphate groups from many types of molecules, including nucleotides, proteins, and alkaloids (Arceci et al., 2006). In this study, LC25 of Diazinon was tested to reveal its histopathological effect on the ovotestis of $M$. cantiana because of its direct effect on reproductive organs. In rats, intraperitoneal administration of Diazinon damaged their testis germinal epithelium leading to spermatogenesis failure after $36 \mathrm{~h}$ and resulted in infertility (Cabaja et al., 2010). Severe damages occurred in the hermaphrodite gland of B. alexandrina treated with both Albendazode and Nitazode pesticides (El-Enain et al., 2015). The present study was conducted to evaluate the effects of sublethal concentrations of three different pesticides applied as baits against M.cantiana, namely, Diazinon (organophosphate), Lambdacyhalothrin (pyrethroids) and Methomyl (carbamate) on the activities of five vital enzymes.

\section{Material and Methods}

Tested snails: Adult snails of $M$. cantiana were collected from infested gardens and field crops in Zagazig city, Sharkia Governorate, Egypt, during the spring period of 2015. The collected snails were transferred in plastic bags to the laboratory, then kept in five plastic cages $(40 \times 30 \times 30 \mathrm{~cm}$, with 20 individuals / cage) filled with moist sterilized sandy loamy soil $1: 1(\mathrm{v}: \mathrm{v})$ and fed on fresh leaves of lettuce for 14 days to be laboratory acclimatized.

Tested Pesticides: $\mathrm{LC}_{50}(5 \mathrm{ppm})$ of three different pesticides with chemically different groups were tested according to Genena et al., 2003. Their trade names, common names, chemical groups and chemical structures are listed in Table (1).

Table (1): List of tested pesticides, their common names, trade names, chemical groups and chemical structures.

\begin{tabular}{|c|c|c|c|}
\hline Common name & Trade name & Chemical group & Chemical structure \\
\hline Diazinon & $\begin{array}{c}\text { Diazinon (60\% } \\
\text { E.C.) }\end{array}$ & Organophosphate & \\
\hline $\begin{array}{c}\text { Lambda- } \\
\text { cyhalothrin }\end{array}$ & $\begin{array}{c}\text { Karate 20\% EC } \\
\text { Methomyl }\end{array}$ & $\begin{array}{c}\text { Lannate (90\% } \\
\text { W.P.) }\end{array}$ & Carbamate \\
\hline
\end{tabular}

Experimental design: The experiment took place under laboratory conditions at $22 \pm 1^{\circ} \mathrm{C}$ and $60 \pm 2 \%$ R.H. The three pesticides were applied as baits against the land snails. Ten adult snails with similar sizes were transferred from stock culture to plastic cups $10 \mathrm{~cm}$-diameter filled with $100 \mathrm{~g}$ moist sterilized sandy: loamy soil 1:1 (v:v). Each cup was covered with muslin cloth held by rubber bands. Biochemical studies were made after $96 \mathrm{~h}$ of treatment.

\section{Biochemical studies:}

Sample preparation: After 96 h of exposure to LC50 of tested pesticides, 
shells of tested snails were removed by making a cut around the whorls in a continuous manner, starting at the aperture opening using a scissor. Broken fragments of the shells were carefully removed. Snail tissues were dissected, homogenized and centrifuged at $8000 \mathrm{rpm}$ for $15 \mathrm{~min}$. at $5^{\circ} \mathrm{C}$ in refrigerated centrifuge. The deposits were discarded and the supernatants were kept in a deep freezer till use to determine the levels of (CAT), (MDA), (AST), (ALT) and (ALP) in tissues of control and treated snails.

\section{Biochemical measurements:}

CAT activity was assayed by the method of Aebi (1984). The activity of ALT and AST were determined according to the procedure of Reitman and Frankel (1957). (ALP) was measured according to Simko (1991). Hepatic (MDA) was analyzed according to Uchiyama and Mihara (1978). All biochemical measurements were determined by using kits in the unit of micro-chemical analysis at National Research Center, Giza, Egypt.

\section{Histological Studies:}

Hermaphrodite glands of $M$. cantiana, either control or Diazinon treated snails for 7 days, were dissected out and fixed in Bouin's fluid. The fixed samples were dehydrated in a series of ethanol, cleared and embedded in paraffin wax. Sections of $5 \mu \mathrm{m}$ thickness were cut, stained with haematoxylin and eosin and examined with a binuclear microscope.

Statistical analysis: Data were calculated as Mean \pm SD and analyzed using analysis of variance technique (ANOVA) followed by Least Significant Difference (LSD). Probability of 0.05 or less was considered significant. All statistical analysis was done by CoHort Software (2004).

\section{Results}

Activity of Malondialdehyde (MDA): Table(2) showed clearly that Methomyl was found to be the most effective pesticide in increasing the level of MDA enzyme in tissue homogenate of $M$. cantiana followed by Lambda-cyhalothrin and Diazinon, respectively. On the other hand, Diazinon did not cause significant differences between control and treated snails.
Activity of Catalase enzyme (CAT): Data in Table (2) indicated that, CAT activity was increased in $M$. cantiana after treatments with all tested pesticides. There were significant differences in enzymatic levels of treated snails and control. Methomyl and Lambada induced the highest increase in catalase activity, respectively. Diazinon was found to produce the lowest increase level.

Activity of Alanine transaminase (ALT) Table (2) showed that all tested pesticides increased the level of (GPT) when applied against the land snail, $M$. cantiana. Whereas, Diazinon caused the lowest increase level and induced no significant difference in the activity of this enzyme.

Activity of Aspartate transaminase (AST): Table (2) indicated that Methomyl cause the highest increase level in the activity of (AST) followed by Lambdacyhalothrin. While, D i a z i n o n, caused the lowest activity of (AST) compared to control.

Activity of Alkaline phosphatase
(ALP): The activity of alkaline
phosphatase (ALP) in the tissue
homogenate of the land snail $M$. cantiana
was represented in Table (2). Data
indicated that all tested pesticides
significantly increased the levels of this
enzyme. Methomyl treated snails had the
highest increase levels of (ALP).

Histology of the hermaphrodite gland of M.contiana

\section{Untreated snails:}

The hermaphrodite gland (ovotestis) is located in the posterior part of visceral mass and is partly embedded in the digestive gland. It is composed of a large number of oval or rounded acini (A) in which male and female gametes are developed (Fig.1). The acini correlated with spermatogenesis are separated by connective tissue (CT). Spermatogonia (SG) are differentiated from the germinal epithelium (GE) and their supporting Sertoli cells (SR) usually arranged in clusters. They are often found along the wall in the proximal part of the acinus (Fig.2). Spermatogonia are small rounded cells, increase in number and develop into primary and secondary spermatocytes. These rounded cells developed into elongated cells, spermatids (SPR), which developed into spermatozoa(S). Long-tailed spermatozoa accumulated within the lumen (L) of acini (Fig. 3).

Treated snails: The present result showed severe damages in the histology of hermaphrodite gland of $M$. cantiana after exposure to $2.5 \mathrm{ppm}$ of Diazinon pesticide. 
The acini of the ovotestis suffered from many histopathological alterations (Figs.4,5,6). The ovotestis exhibited severe disruption of germinal epithelium, their supporting Sertoli cell (SR) and reduction in the intensity of sperm (S) within the acini.
Some acini appeared to have few stages of male gametes. The spermatogenic cells in most of the acini had affected or probably inhibited to develop to the late stages of spermatogenesis

(Fig.6)

Table (2): Enzymatic levels (means \pm S.D.) in the land snail, $M$. cantiana tissues exposed to 5 ppm of three different pesticides for $96 \mathrm{~h} .:$

\begin{tabular}{|c|c|c|c|c|c|}
\hline Character & $\begin{array}{c}\text { MDA } \\
(\mathrm{n} \mathrm{mol} / \mathrm{g})\end{array}$ & $\begin{array}{l}\text { CAT } \\
(\mathrm{U} / \mathrm{g})\end{array}$ & $\begin{array}{l}\text { ALT } \\
(\mathbf{U} / \mathbf{L})\end{array}$ & $\begin{array}{l}\text { AST } \\
(\mathbf{U} / \mathbf{L})\end{array}$ & $\begin{array}{c}\text { ALP } \\
(\text { IU/ g) }\end{array}$ \\
\hline Control & $156.3 \pm 3.3$ & $0.18 \pm 0.04$ & $20.13 \pm 1.4$ & $26.7 \pm 2.4$ & $13.6 \pm 2.9$ \\
\hline Diazinon & $160.9 \pm 2.02$ & $0.24^{*} \pm 0.01$ & $23.03 \pm 2.4$ & $27.4 \pm 1.8$ & $13.8 \pm 0.3$ \\
\hline $\begin{array}{l}\text { Lambda- } \\
\text { cyhalothrin }\end{array}$ & $189.8^{*} \pm 0.8$ & $0.36^{*} \pm 0.2$ & $27.4^{*} \pm 0.8$ & $37.9^{*} \pm 1.9$ & $18.7^{*} \pm 0.9$ \\
\hline Methomyl & $245.4^{*} \pm 25.8$ & $0.41^{*} \pm 0.03$ & $28.8^{*} \pm 1.5$ & $40.3^{*} \pm 1.9$ & $22.5^{*} \pm 1.9$ \\
\hline
\end{tabular}

Asterisks denote a significant $\left({ }^{*} \mathrm{P}<0.05\right)$.

Malondialdehyde (MDA), Catalaze (CAT), Alanine transaminase (ALT), Aspartate transaminase (AST), Alkaline phosphates (ALP).

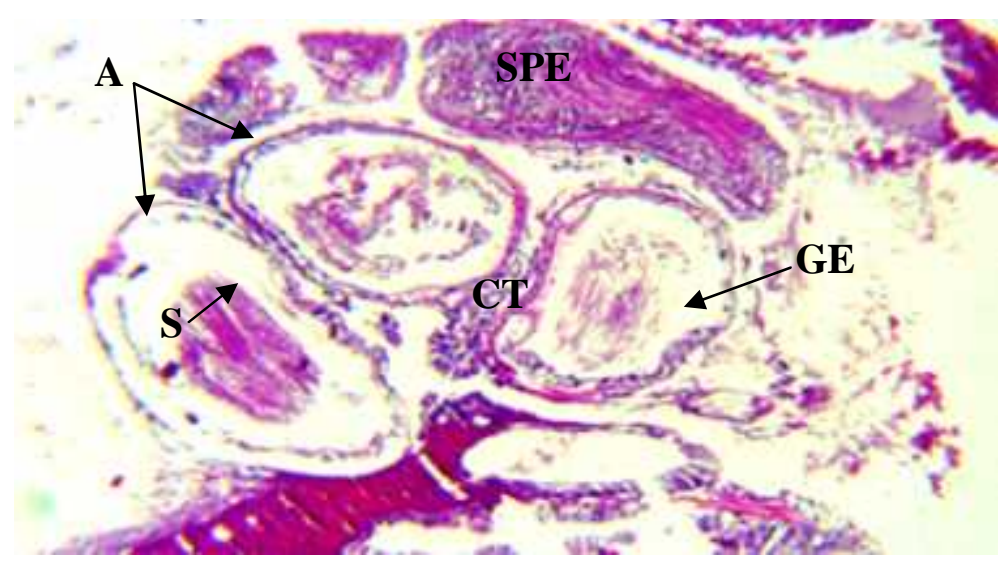

Figure (1): Photomicrograph in the hermaphrodite gland of untreated $M$. contiana indicating many acini connected with connective tissue (CT) and lined with germinal epithelium (GE ), filled with different stages of spermatocytes (SPE), and mature sperms (S). $(\boldsymbol{X}=\mathbf{1 0 0})$

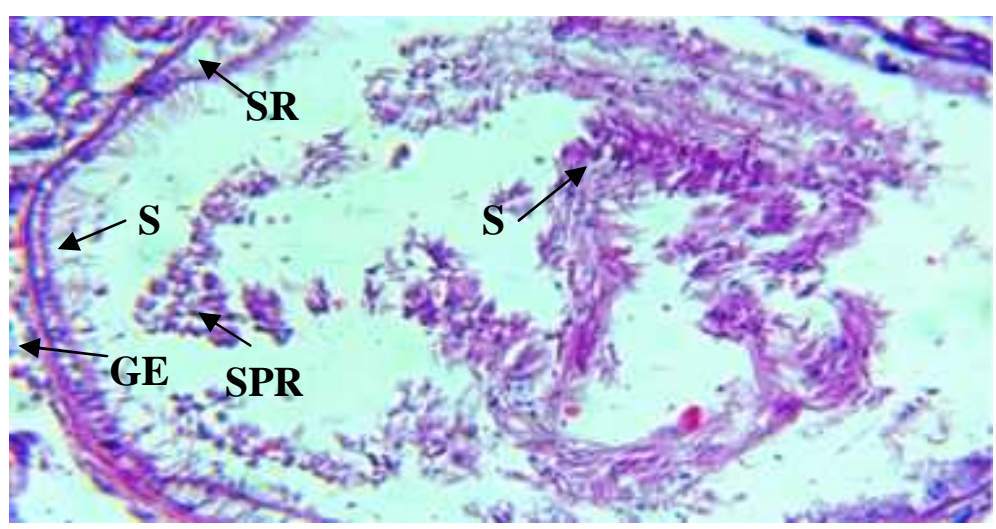

Figure (2): Photomicrograph in the hermaphrodite gland of untreated $M$. contiana snails showing the normal structure of an acinus including germinal epithelium (GE), Sertoli cell (SR), spermatogonia, different stages of spermatocytes (SPE), These rounded cells developed into elongate cell, spermatids (SPR), which developed into spermatozoa(S). (X=200) 


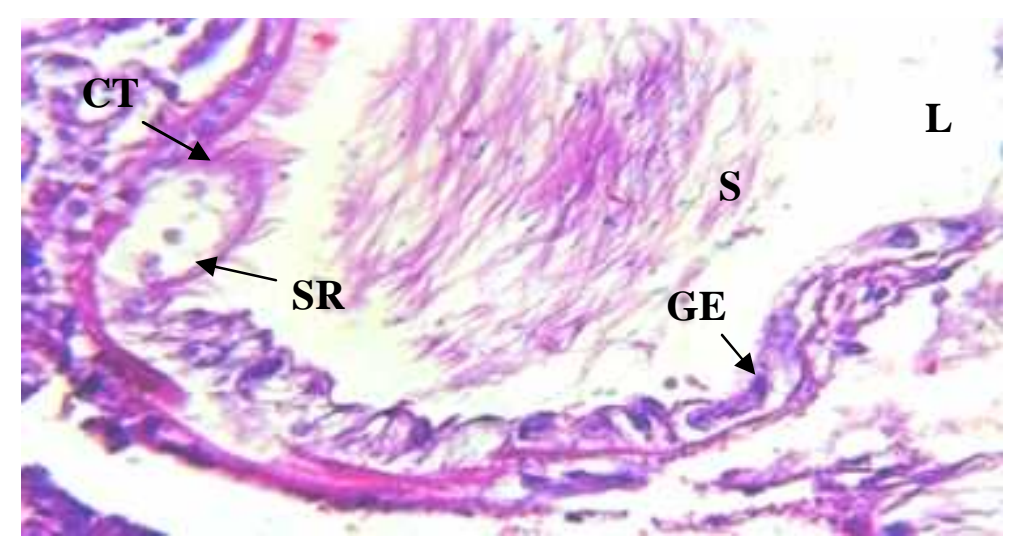

Figure (3): Photomicrograph in the hermaphrodite gland of untreated $M$. contiana snails showing a highly magnified acinus surrounded by connective tissue (CT) and germinal epithelium (GE), Sertoli cell (SR), spermatogonia, different stages of spermatocytes (SPE), spermatids (SPR), and clusters of mature sperms $(\mathrm{S})$ in the lumen $(\mathrm{L})$. $(X=400)$

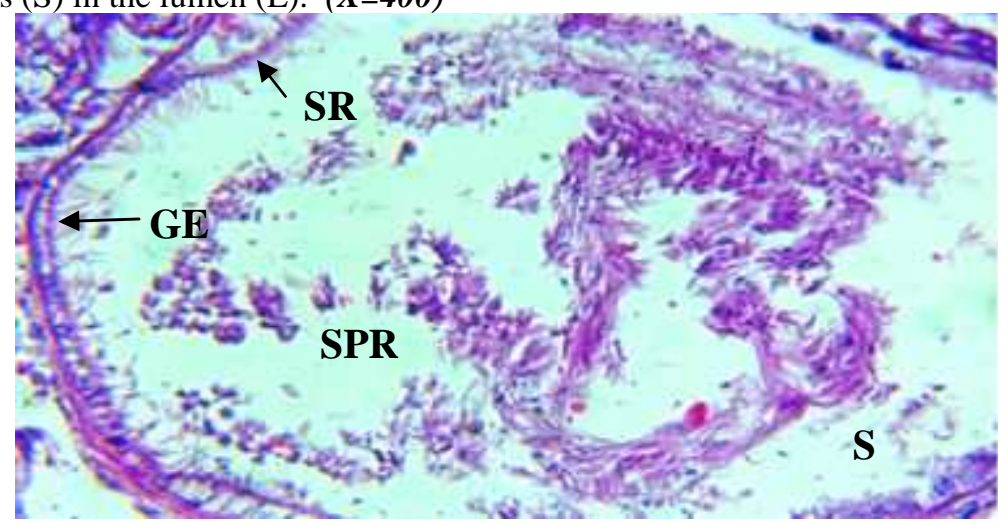

Figure (4): Photomicrograph in the hermaphrodite gland of $M$. contiana treated with 2.5ppm Diazinon showing, destruction of germinal epithelium (GE) , Sertoli cells(SR), spermatids (SPR), and few scattered sperms (s). $(X=400)$

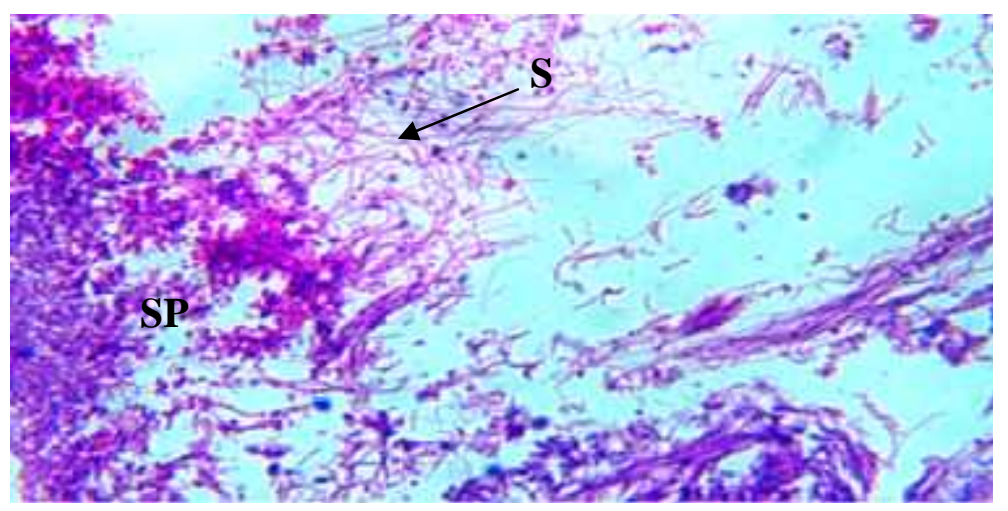

Figure (5): Photomicrograph in the hermaphrodite gland of $M$. contiana snails treated with $2.5 \mathrm{ppm}$ Diazinon showing that spermatids(SP) are inhibited to reach maturity and sperms (S) decreased in numbers and have bizzar shaped. $(\boldsymbol{X}=\mathbf{4 0 0})$ 


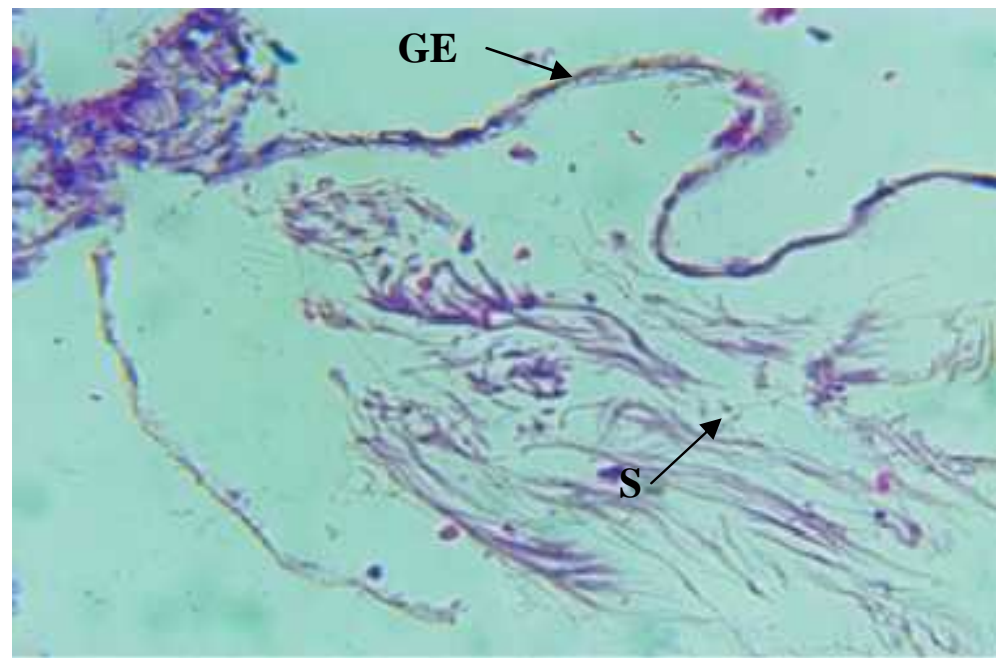

Figure (6): Photomicrograph in the hermaphrodite gland of $M$. contiana snails treated with $2.5 \mathrm{ppm}$ showing destruction of germinal epithelium (GE) and reduction in sperm numbers $(\mathrm{S})$. ( $\boldsymbol{X}=\mathbf{4 0 0})$

\section{Discussion}

The obtained results in this study provided that the tested pesticides caused alterations in some biochemical and histopathological targets which could lead to serious metabolic and cellular damages. In general, the three pesticides affected the activities of five vital enzymes, when applied against the tested land snail $M$. cantiana. The present study revealed also that sublethal concentrations of tested pesticides increased the activities of (CAT), (MDA), (AST), (ALT) and (ALP) in the tissue homogenate. Transaminase enzymes; AST and ALT are not solely located in hepatocytes but also in many body organs. (AST/ALT ratio) are commonly measured clinically as biomarkers for liver health (Ghouri et al., 2010). Also, the elevation in their activities could be due to a variety of conditions including muscle damage, intestinal and hepatic injury and toxic hepatitis (Farkas et al., 2004). (AST) increment levels after exposure to pesticides in this study was in accordance with Felix Wróblewski et al., (1956) who found that (AST) activity increases two to 20 times following acute myocardial infarction, and may rise to 20 to 500 times normal in acute hepatitis due to toxins. Bakry et al., (2013) reported that exposure of Bulinus truncatus to sub lethal concentrations of glyphosate for two weeks increased the activities of lipid peroxidase (LP), sorpitol dehydrogenase (SDH) and transaminases

Accordingly, the present elevations in the activities of (AST) and (ALT) enzymes in tissues of treated $M$. cantiana could be partially due to cell injury of their different organs and this may be led to disturbances in their enzymatic systems (Mahmoud ,2006). These results support the findings of Radwan et al., (1992) who found that carbamate compounds lead to significant elevation of the activity of (AST and ALT) when applied against the land snail Theba pisana. Thus, the deviation of both enzymes activities out of the normal range could lead to biochemical impairment and lesions of the tissues and cellular functions.

Alkaline phosphatase (ALP) is a hydrolase enzyme responsible for removing phosphate groups from many types of molecules, including nucleotides, proteins, and alkaloids. (Arceci et al., 2006). Mixed-function oxidase (MFO) an enzyme complex found in animals that oxidize toxic compounds to render them. This enzyme is localized in hepatopancreas in invertebrates. The present study indicated that Metaldehyde compounds caused an increase in the level of (MFO) in tested land snails. Malondialdehyde (MDA) increased levels in this study is a marker for oxidative stress. This finding is in agreement with Davey et al., (2015) who mentioned that (MDA) results from lipid peroxidation of polyunsaturated fatty acids and the degree of lipid peroxidation can be estimated by the amount of malondialdehyde in tissues.

Carbamate compounds was found to be the most inhibitory compounds to AchE when applied against the land snail, $M$. cantiana. These results support the finding of Radwan et al., (1992) who found that some carbamate compounds such as methiocarb induced reductions in the activity of AchE in the land snail, Eobania vermiculata. Also, Daoud (2010) indicated that carbamates gave a significant decrease in AchE activity in the two land snails, Cochlicella acuta and Succinea putris. 
Bakry et al., (2013) reported that residues of Diazinon and Profenofos pesticides affected fatty acid profile, antioxidant enzymes, protein patterns and caused reduction in survival rate and egg production in treated $B$. alexandrina snails. The results indicate that sublethal concentration of Diazinon, has a toxic effects and cellular damages of the ovotestis of $M$. contiana. This cellular damage could be correlated with the disturbed enzyme activities in the present study. The present result showed severe damages in the hermaphrodite gland of $M$. cantiana after exposure to sublethal concentration of Diazinon pesticide. The acini of the ovotestis suffered from many pathological alterations. Some acini appeared to have few stages of male gametes. The spermatogenic cells in most of the acini had affected or probably inhibited to develop to the late stages of spermatogenesis. Oocytes were not observed in the acini. The ovotestis exhibited severe disruption of germinal epithelium and reduction in the intensity of sperm within the acini. The present results are in line with the observation of Mohamed (2000) on the freshwater snail $B$. alexandrina who found that the pesticide abamectin, inhibits the gametogenesis inhibition of the gonadotropic hormones (El Gohary et al., 2011). The pesticides may greatly suppress the secretion of steroidal sex hormones responsible for maturation of the hermaphrodite gland and stimulation of gametogenesis (El-Nahas, 1998). El-Feky et al., (2009) studied the physiological and histopathological effect of Tributyletin on Lymnaea natalensis and Physa acuta, the result showed that exposure to two weeks and six weeks the ovotestis exhibited not only a severe disruption of germ cells formation but also reduction in the intensity of sperm and follicle within the acini of both treated snails. El-Enain et al., (2015) revealed severe damages in the hermaphrodite gland of $B$. alexandrina treated with both Albendazode and Nitazode pesticides .This indicates that Diazinon pesticides cause a high degree of cessation of gametogenesis and sterility in the land snail $M$. contiana causing infertility and limitation of its population density.

\section{Competing interests}

The authors declare that they have no competing interests.

\section{References}

Aebi, H. (1984). Catalase in vitro. Methods in Enzymology .105, 121-126.

Alahyary,P., Ilkhani,M. and Fathy,F. (2008). The potential toxicity of Diazinon on physiological factors in male rabbits. Pakistan Journal of Biological Science. 11(1):126-130.

Arceci, R.J., Hann I.M. and Smith, O.P. (2006). Pediatric hematology (3rd ed.). WileyBlackwell. p. 763.

Bakry, F.A., El-homossany, K. and Abd ElAtti, M.S. and Ismaiel, S.M. (2013). Alterations in the fatty acid profile, antioxidant enzymes and protein pattern of Biomophalaria alexandarina snails exposed to the pesticides diazinon and profenofos. Global J Pharm.Pharmacol 1(1):2736.

Cabaja,M.,Toman,T.,Adamkovicova,M.,Mas sanya, p., Siska, B. and Lukac,N. (2010). Structural changes in the rat testis caused by Diazinon and Selenium. Potravinarstvo 4:8-16.

CoHort Software (2004). CoStat. California, USA.

Daoud, M.I.A. (2010). Toxicological and biological studies on some terrestrial snails and slugs at Dakahlia Governorate. Ph.D. Thesis, Faculty of Agriculture, Al-Azhar Unevrsity.

Davey, M.W., Stals E., Panis B., Keulemans J.and Swennen, R.L. (2005). High-through put determination of malondialdehyde in plant tissues. Analytical Biochemistry 347 (2): 201207.

Ebenso, I. E., Ita, B., Umoren, E. P., Ita, M., Binang, W., Edet, G., Izah, M., Udo, I. O., Ibanga, G. And Ukpong, E. E. (2005). Effect of carbamate molluscicide on african giant land snail Limicolaria Aurora. J. Appl. Sci. Environ. Mgt. 9 (1) :99 - 102 .

El Gohary, R.A. Laila and Marwa A.M. Genena (2011). Biochemical Effect of Three Molluscicide Baits Against the Two Land Snails, Monacha cantiana and Eobania vermiculata (Gastropoda: Helicidae). International Journal of Agricultural Research 6(9):682-690.

El-Enain, L.G., Sharaf, H.M. and Abd ElAtti, M.S. (2015). Antischistosomal impact of Albedazode and Nitazode on Schistosoma mansoni larval stages. African journal of Microbiology Research,9(6):.349-403

El-Feky, F., Raafat, H.A. and Kamal, H. (2009). Physiological and histopathological effects of tributyletin (TBT) on Lymnaea natalensis and Physa acuta. The Egyptian Journal of Hospital Medicine. 37: 610-620.

El-Nahas, H.A. (1998). Effect of sublethal concentrations of some plant molluscicides on survival and fecundity of Biomphalaria alexandrina,. Egypt. J. Biomed. Sci. 2: p27-39. 
Essawy, A.E, Abdelmguied, N.E, Radwan, M.A., Hamed,S.S., and Hegazy, A.E. (2000). Neuropathological effect of carbamate molluscicides on the land snail (Eubania vermiculata). Cell Biol., 25:275-290.

Farkas, J.P., Farkas, P. and Hyde, D. (2004). Liver and Gastroenterology Tests. In: Basic Skills in Interpreting Laboratory Data, Lee, M. (Ed.). 3rd Edn., American Society of Health System Pharmacists Inc., USA., pp: 330-336.

Felix Wróblewski, M.D., George Jervis, M.D., John, S. and Ladue, M.D. (1956). The diagnostic, prognostic and epidemiologic significance of serum glutamic oxaloacetic transaminase (sgo-t) alterations in acute hepatitis. Ann Intern Med. 45(5):782-800.

Geller, R. J., Lopez, G.P., Cutler, S., L., Diana, B., George F. and Gorman, Susan E. (2003) . Atropine availability as an antidote for nerve agent casualties: Validated rapid reformulation of high-concentration atropine from bulk powder. Annals of Emergency Medicine 41 (4): 453-6.

Genena, M. A.M. (2003). Studies on the terrestrial gastropods at Dakahlia Governorate. M.Sc. Thesis, Fac. Agric., Mansoura Univ. 136 pp.

Ghouri, N., Preiss, D., and Sattar, N. (2010). Liver enzymes, nonalcoholic fatty liver disease, and incident cardiovascular disease: a narrative review and clinical perspective of prospective data. Hepatology 52 (3): 1156-61.

Góth L, Bigler, W.N. (2001). Blood Catalase Deficiency and Diabetes in Hungary. Diabetes Care 24 (10): 1839-1840.

Howard, P. H. (1991). Handbook of Environmental Fate and Exposure Data for Organic Chemicals: Pesticides. Chelsea, MI: Lewis Publishers. pp. 3-15.

Imevbore, E. A and Ajayi, S.S. (1993). Food preference of the african giant snail, Archachatina marginata in captivity. African Journal of Ecology 31:265-267.

Mahmoud, M.B. (2006). Biological and histological impact of the insecticides reagent and mimic on Biomphalaria alexandrina snails. Egypt. J. Zool., 46: 11-21.

Mohamed, A.M., Bakry, F.A. and Heiba, F.N. (2000). Effect of abamectin as a molluscicide on survival, fecundity and cercarial shedding of the freshwater snail Biomphalaria alexandrina infected with Shistosoma mansoni. First Internat. Conf.Biol.Sci., Faculty of Science, Tanta University, 1:207-216.
Ohayo, G.J.A., Heederik, D.J.J., Kromhout, H.; Omondi, B.E.O. and Boleij, J.S.M. (1997).Acetylcholinesterase inhibition as an indicator of organophosphate and carbamate poisoning in Kenyan agricultural workers. International Journal of Occupational and Environmental Health, 3: 210-220.

Radwan, M.A., El-Wakil, H.B. and Osman, K.A (1992).Toxicity and biochemical impact of certain oxime carbamate pesticides against terrestrial snail, Theba pisana (Muller). J. Environ. Sci. Health Part B: Pestic. Food Contam. Agric. Wastes, 27: 759-773.

Reitman, S. and Frankel, S. (1957). A colorimetric method for the determination of serum glutamic oxalacetic and glutamic pyruvic transaminases. Amer. J. Clin. Pathol. 28: 56-63.

Sharom, M.S., Miles, J.R.W., Harris, C.R. and McEwen, F.L. (1980). Behaviour of 12 insecticides in soil and aqueous suspensions of soil and sediment. Water Research 14 (8): 1095 100.

Simko, V. (1991). Alkaline phosphatase in biology and medicine. Dig. Dis., 9: 189-209

Uchiyama, M. and Mihara, M. (1978). Determination of malonaldehyde precursor in tissues by thiobarbituric acid test. Anal.Biochem., 86, 271. 278.

Vijverberg H.P.and van den Bercken J. (1982). Action of pyrethroid insecticides on the vertebrate nervous system. Neuropathol. Appl. Neurobiol.8 (6):421-440.

Wilkinson,C.F. (1976). Insecticide biochemistry physiology. Hyden Verlag, London.

Young, A.G. and Wilkins ,R.M. (1989): The response of invertebrate acetylcholinesterase to molluscicides. Proceedings of the British Crop Protection Council, 41:121-128.

Zedan, H.A., Mortada, M.M. and Shoei, B, A.A. (2006). Assessment of molluscicidal activity of certain pesticides against two land snails under laboratory and field circumstances at Dakahlia Governorate. J. Agric. Sci. Mansoura Univ., 31: 3957-3962. 
Journal of Bioscience and Applied Research, 2015, Vol.1, No.2, PP.59-67, $\quad$ pISSN: 2356-9174, eISSN: $2356-9182$ 147 